\title{
Эллинистическо-иудейские и древнехристианские исторические сочинения в «Библиотеке» Фотия
}

\author{
А.А. Логвинова \\ Белгородский государственный национальный исследовательский университет, \\ Россия, 308015, г. Белгород, ул. Победы, 85 \\ E-mail: aleksandra.kostyukovich@mail.ru
}

\begin{abstract}
Аннотация. Статья посвящена изучению труда «Мириобиблион» константинопольского патриарха Фотия (IX в.), а конкретно протохристианских произведений в нем. Эти произведения играли важную роль в становлении ранней христианской литературы, стоя на стыке иудаизма, античной философии и христианства. Через них осуществлялся синтез восточной и западной традиции. В «Мириобиблионе» Фотия предпринята попытка интегрировать их в культурный пласт христианской литературы, несмотря на то, что религиозно-философские взгляды их авторов зачастую серьезно отличаются от христианских догматов. Особое внимание уделено эллинизированному иудею Иосифу Флавию, произведениям которого Фотий посвящает 4 кодекса. Изучение аннотаций Фотия показывает, что протохристианские произведения в целом позитивно воспринимались в византийском обществе, они вызывали интерес прежде всего с точки зрения описания новозаветных событий «изнутри». Однако все же таких произведений было мало, в «Мириобиблионе» всего 7 подобных сочинений из 280.
\end{abstract}

Ключевые слова: Поздняя античность, Фотий, «Мириобиблион», кодекс, протохристианские сочинения, Иосиф Флавий.

Для цитирования: Логвинова А.А. 2020. Эллинистическо-иудейские и древнехристианские исторические сочинения в «Библиотеке» Фотия. Via in tempore. История. Политология, 47 (4): 754-762. DOI: 10.18413/2687-0967-2020-47-4-754-762.

\section{Hellinistic-judaic and ancient Christian historical works in the «Library» of Photius}

\author{
Alexandra A. Logvinova \\ Belgorod National Research University, \\ 85 Pobeda St., Belgorod, 308015, Russia \\ E-mail: aleksandra.kostyukovich@mail.ru
}

\begin{abstract}
The article is devoted to the study of the work «Myriobiblion» by the Patriarch of Constantinople Photius (IX century), and specifically the proto-Christian works in it. These works played an important role in the formation of early Christian literature, standing at the junction of Judaism, ancient philosophy and Christianity. Through them the synthesis of Eastern and Western literary traditions was carried out. Photius' Myriobiblion attempts to integrate them into the cultural layer of Christian literature, despite the fact that the religious and philosophical views of their authors are often seriously different from Christian dogmas. Particular attention is paid to the hellenized Jew Joseph Flavius, whose works Photius devotes as many as 4 codes. A study of Photius's annotations shows that proto-Christian works, in general, were positively perceived in Christian society, they aroused interest primarily from the point of view of describing New Testament events «from the inside». However, there were still few such works, in «Miriobiblion» we counted only 7 such works out of 280.
\end{abstract}

Keywords: Late antiquity, Photius, «Myriobiblon», code, proto-Christian writings, Josephus Flavius. 
For citation: Logvinova A.A. Hellinistic-judaic and ancient Christian historical works in the «Library» of Photius. Via in tempore. History and political science, 47 (4): 754-762 (in Russian). DOI 10.18413/2687-0967-2020-47-4-754-762.

Рецепция византийской традиции пользуется неизменным интересом у зарубежных и отечественных историков. Несомненно, в историческом аспекте ценность представляет «Мириобиблион» интеллектуала IX века патриарха Фотия как важнейший памятник рецепции. Это книга, представляющая собой собрание различных прочитанных византийским интеллектуалом античных и средневековых произведений разных авторов. Всего он содержит 280 аннотаций и выписок из различных произведений. «Мириобиблион» по количеству цитируемых кодексов состоит на 43,6\% из светских и на 56,4\% - из христианских произведений. А по реальному объему (количеству страниц) наоборот, 58\% составляют светские и только $42 \%$ - христианские тексты.

Особый интерес представляют светские произведения протохристианской традиции и их описание в «Мириобиблионе». Эта литература относилась к периоду I-III вв., являясь наиболее аутентичной для описания жизни Христа и зарождения христианской Церкви именно в историческом плане, и игнорировать ее было невозможно. В то же время она сложно интегрировалась в ортодоксальное христианское вероучение, так как христианство как религия в то время еще не сложилось, не было выработано догматов и канонов, поэтому авторы зачастую разделяли те взгляды, которые в последующем были осуждены как ереси. Вариант интеграции данной литературы в культурно-исторический пласт христианского общества показан в «Мириобиблионе» Фотия. Кроме того, изучение данной темы позволяет взглянуть на такое важное культурное явление первых веков нашей эры, как встреча восточной и античной литературных традиций, их синтез и взаимовлияние, обусловившие генезис собственно христианской литературы. Причем это дается сквозь призму христианского мировоззрения, которое может наиболее глубоко отразить все нюансы этой проблемы.

Зарождение христианской литературы происходило на грани двух разнородных стилевых и языковых миров - еврейско-арамейского и греческого. Она разрушила эту грань самим своим возникновением, разорвав замкнутый круг античной литературы и открыв ее к восприятию нового влияния. Распространение новой религии, а с ней и новой литературы, должны были по необходимости перестроить в корне не только формальный, но и идейный строй латиноязычной и грекоязычной словесности - и при этом с самыми длительными последствиями. Мир старых устоявшихся форм и тем был взорван.

Греко-римская литература была довольно закрытой для внешних воздействий. Обусловлено это отчасти тем, что развивалась она на ином уровне, чем восточные литературы, соседствовавшие с ней географически [Семеновкер, 1995, с. 142]. Мир классической древности смог добиться того, чего не смогли многие великие культуры, - он дал литературе независимость от культа и быта, а также выработал теоретическое высоко сознательное отношение к слову, то есть породил риторику и поэтику. До тех пор, пока языческая, античная Греция оставалась сама собой, она не воспринимала красоту чужого слова [Пети, 2004, с.125-127]. Сам тип литературы латино- и грекоязычного мира качественно изменился на переходе от античности. Эту органическую эволюцию было бы в корне неверно объяснять механическими влияниями Востока, но неоспоримым является то, что преклонение перед Библией было сильнейшим фактором в литературном процессе тех веков. Найти за пределами замкнутого круга собственной классики точку опоры христианизировавшейся греко-латинской литературе помогло знакомство с восточной традицией, тем самым были созданы предпосылки к решению новых задач [Лемерль, 2012, с. 61-70].

Христианство первых трех веков с юридической точки зрения оказалось в положении «недозволенной религии», отказ христиан от участия в официальных языческих куль- 
тах называли святотатством, а христианские общины попадали в категорию «незаконных собраний». В этот период со стороны образованных язычников появились первые нападки на христиан. Во II в. главными оппонентами христианства стали автор сочинения «Истинное слово», направленного против христиан, Цельс и наставник императора Марка Аврелия Фронтон. Они рассматривали христианство как учение, которое полно фанатизма и предрассудков и угрожает античному миросозерцанию. Кроме этого, о христианах распространялось множество сплетен и клеветы, вызванных отчасти закрытостью их собраний. Задача древнехристианских авторов заключалась в том, чтобы с самых разных сторон продемонстрировать приемлемость христианства языческому миру - философскобогословской, гражданской, культурной, религиозной и т. д. [Васильев, 2012, с. 55-58]. Прежде всего, древнехристианские авторы старались опровергнуть клевету, возводимую на христиан, и ответить обвинителям Церкви, говорившим о том, что она - угроза государству. Также они раскрывали безнравственность и абсурдность язычества, его божеств и мифологии и утверждали, что единственно верным учением о мире и Боге обладает христианство. Они опровергали аргументы философов и показывали, что сама их философия не может достичь истины, имея человеческий разум единственным обоснованием. Кроме того, они опровергали возводимые на христиан обвинения в чудовищных преступлениях (эдиповы кровосмешения, каннибализм, атеизм и др.), доказывая их абсурдность и невозможность [Плотников, с. 2011, с. 81-90].

Вместе с тем предыстория переворота, осуществленного христианством в средиземноморской литературе, началась еще за три века до возникновения самого христианства - с создания Interpretatio Septuaginta Seniorum («Перевод семидесяти толковников») ${ }^{42}$. Александрийские евреи в годы царствования монарха Птолемея Филадельфа II (285-246 гг. до н. э.) перевели на греческий язык Пятикнижие, то есть пять первых и самых важных книг Ветхого Завета. На этом переводческая работа не остановилась: уже ко второй половине II в. до н. э. на греческий были переведены почти все книги Ветхого Завета. В скором времени появилось в греческом переводе и все остальное [Кащеев, 1997, c.11-19].

От собственно древнехристианской литературы (вторая половина I - начало II в.) до нас, прежде всего, дошел Новый Завет - комплекс религиозных сочинений, которые были выбраны как самое адекватное выражение новой веры из множества подобных им и вместе с Септуагинтой составляли христианскую Библию. В новозаветных текстах отражалась квинтэссенция христианского учения [Зелинский, 1996, с. 22-26]. Однако писания Нового завета составляли лишь незначительную часть обширной протохристианской литературы, которая создавалась в I-III вв., то есть до разрешения христианства и его последующего принятия как официальной религии [Блаватская, 1983, с. 6-14].

Деятельность древнехристианских авторов частично была уже подготовлена эллинистическим иудаизмом, стоявшем на стыке иудаизма, язычества и христианства: Филон Александрийский написал такие несохранившиеся сочинения, как «Основания» и «Апология в защиту иудеев». Иосифу Флавию принадлежала апология «О древности иудейского народа, против Апиона», оказавшая влияние на некоторых авторов. Также важны такие произведения Иосифа Флавия, как: «О бедствиях евреев», «О Вселенной», называемый также «О природе Вселенной» и «О причинах Вселенной»; «Иудейские древности»; «Иудейские войны» [Шаму, 2008, с. 170-177].

В «Мириобиблионе» Фотия представлены несколько кодексов этого рода. Четыре из них посвящены произведениям Иосифа Флавия (ок. 37 - ок. 100 гг. н. э.): кодекс 47 «О бедствиях евреев», 48 - «О Вселенной», 76 - «Иудейские древности», 238 - «Иудейские войны». Такое внимание Иосифу Флавию, что каждая его работа рассматривается в

${ }^{42}$ Собрание переводов Ветхого Завета на древнегреческий язык, выполненных в III-I вв. до н. э. в Александрии. Часто обозначается как «LXX». 
отдельном кодексе, может быть связано с тем, что Фотий читал их в отдельных рукописях, однако также свидетельствует об уважении, которое испытывал византийский интеллектуал к Иосифу.

Кроме этого, Фотий читал произведение Юста Тивериадского (I в.) «Хроника иудейских царей», которому посвящен кодекс 33, а также «Хронику» Секста Юлия Африкана (ок. 160-240 гг.), которую он характеризует в кодексе 34. Еще одно произведение, тематически относящееся к этой группе - анонимный трактат об исчислении Пасхи, который описан в кодексе 116.

В кодексе 47 «Мириобиблиона» Фотий пишет, что прочитал труд иудея Иосифа Флавия «О бедствиях евреев». Там Иосиф описал захват Гисхалы, Иотапаты (где он сам был взят в плен), а также уничтожение прочих еврейских крепостей, а в последней книге разрушение крепости Масада и Иерусалима. Работа состоит из семи книг. Фотий не изменяет своей традиции, оценивая «чистый стиль» автора и склонность выражать свои мысли с обаянием, с определенностью и достоинством. Фотий пишет, что Иосиф преподносит свои темы приятно и убедительно, даже если склонен принять противоположные взгляды; он умен, очень любит афоризмы и плодовит в использовании доводов. Также он умело разжигает и успокаивает страсти, привносит эмоции. В своем труде Иосиф рассказывает, что взятию Иерусалима предшествовало множество знаков и предзнаменований. В целом, этот кодекс не содержит оценки работы, кроме той, что дана стилю и языку автора.

В кодексе 48 Фотий описывает философские работы Иосифа Флавия по онтологии и космологии: «Прочитал трактат Иосифа «О Вселенной», который в другом месте называется «О природе Вселенной» и «О причинах Вселенной». Состоит он из двух небольших трактатов, где автор показывает, что Платон противоречит сам себе. Также автор опровергает Алкиноя, чьи взгляды на Воскресение, материю и душу являются абсурдными и ложными, и приводит по этому вопросу свое собственное мнение. Он приводит доказательства того, что еврейский народ намного старше греков. Автор думает, что человек представляет соединение воды, земли и огня, а также духа, называемого им душой. О духе он говорит, что он является главенствующей частью, формируется вместе с телом и пронизывает каждый член и каждый сустав».

Фотий отмечает, что эти взгляды отличаются от еврейских идей относительно человеческой физиологии, и они стоят ниже уровня других сочинений автора. Автором также дается краткий отчет о создании мира. Он говорит, что Христос - истинный Бог, дает ему открыто имя Бога и описывает Его порождение от Отца таким языком, к которому нет никаких возражений. Пожалуй, это могло бы заставить сомневаться, что трактат действительно написал Иосиф, хотя стилистически он от остальных его сочинений не отличается. Далее Фотий приписывает работу Гаю, пресвитеру Рима. Но тем не менее в его кодексах она идет под именем Иосифа Флавия [Henry, 1959, t. I, p. 22]. В целом этот труд оценен Фотием положительно, и он соответствует догматическому учению.

В кодексе 76 Фотием описаны «Иудейские древности» Иосифа Флавия в двадцати книгах. Начинает он с Моисеевой космогонии, и, хотя его отчет в основном согласуется с общепринятым, по словам Фотия, иногда он отличается: «Работа заканчивается войной между римлянами и евреями, когда иудейским царем был Агриппа, сын великого Агриппы, лишивший первосвященства Иисуса, сына Гамалиила, и даровавший его сыну Феофила Маттиасу. Антиох со своим стратегом Лисием были первыми, кто ввел новаторство относительно владения первосвященством. Они сняли с этой должности Онию, именуемого Менелаем, предали его смерти, лишили права наследования его сына, назначив на его место Алкима, звавшегося Иакимом, из рода Аарона, но принадлежавшего другой семье. До этого по закону времен Аарона первосвященник занимал должность в течение всей жизни, а сын наследовал отцу. Но когда умер первосвященник Алким, должность была незанятой семь лет. После Маттиаса с сыновьями семейству Хасмонеев было поручено руководство 
еврейским народом, и первосвященником был назначен Ионатан, пошедший войной на македонян» (ср., Иосиф Флавий, Иудейские древности, XX, 9-11).

Далее Фотий указывает, что автор описывает конец династии Хасмонеев и что Ирод стал с согласия римлян царем евреев: «Первосвященство он даровал кому попало, подавая своим преемникам пример для подражания. В своих двадцати книгах автор от сотворения мира доходит до начала последней войны между римлянами и евреями, до времени, когда Агриппа был назначен римлянами царем евреев, а Гессий Флор сменил наместника Иудеи Альбина. Евреи восстали, не выдержав жестокости и нечестия Флора, решив, что лучше умирать свободными и сразу, чем в рабстве и постепенно. На двенадцатом году правления Нерона, на второй год наместничества Гессия Флора была война, на которой заканчивается труд Иосифа».

В этом кодексе Фотием приведена биография Иосифа: по рождению он был священник и еврей, принадлежащий со стороны отца к семье, происходившей от долгого рода священников. Со стороны матери он был царского рода, так как ее семья происходила от потомков Хасмонея, которые длительное время удерживали и звание царя, и первосвященство. В шестнадцать лет он заинтересовался тремя сектами евреев и стал исследовать их, чтобы, опробовав все их, выбрать лучшее. Это секты ессеев, саддукеев и фарисеев. Пройдя через эти секты, он удалился в пустыню и жил там три года с человеком, жившим одинокой и аскетической жизнью. В девятнадцать лет он вернулся из пустыни и присоединился к фарисейской секте, напоминавшей секту стоиков среди греков. На тридцатом году народ Иерусалима послал его исследовать состояние дел в Галилее, где было большое смятение. Затем его назначили главнокомандующим Галилеи, где он показал себя хорошим администратором.

В 238 кодексе Фотий описывает «Иудейские войны» Иосифа Флавия: «В этой выборке представлено, что он говорит об Ироде: восстановление храма, способ, с помощью которого он узурпировал Иудейский трон, как наследовали власть его потомки и как власть их исчезла в пользу аристократии, когда первосвященники забрали из-под контроля народа преемственность, и все другие связанные с этим события» [ср., Иосиф Флавий, Иудейские войны, I, X-XXXIII]. Хотя текст 238 кодекса является кратким обзором, в нем содержится много точных цитат, показывающих, что Фотий очень внимательно читал этот труд.

Историческая ценность трудов Иосифа Флавия главным образом заключается в том, что они являются основным источником истории евреев с эпохи Маккавеев до завоевания римлянами Иерусалима. Христианские учителя церкви, такие как Тертуллиан, Климент Александрийский, Феофил Антиохийский, и церковные писатели Иероним, Евсевий и другие отзывались об Иосифе Флавии с похвалой, ссылаясь на него как на признанный авторитет [Петровых, 1903, с. 345].

В кодексе 33 Фотий пишет о сочинении Юста из Тивериады «Хроника царей иудейских в виде генеалогии Юста из Тивериады». Свою историю автор начинает от Моисея и доводит до смерти последнего из царя евреев седьмого Агриппы из рода Ирода. Стиль Юста сжатый, и он опускает много фактов, имеющих первостепенное значение. Фотий отмечает, что Юст в своем труде даже не упоминает о пришествии Христа, об исполненных им чудесах или о событиях его жизни: «Отцом его был еврей Пист; сам Юст, по отзывам Иосифа Флавия, был рабом алчности и порока и распутным человеком. Он являлся политическим противником Иосифа, против которого составил, по слухам, несколько заговоров; но Иосиф, хотя он не раз имел в своей власти врага, только словесно отчитал его и отпустил на свободу». Также Фотий писал, что говорят, что написанная Юстом история по большей части является выдуманной, особенно в части описания иудейско-римской войны и взятия Иерусалима. Таким образом, в целом оценка Фотием работы Юста, как и его личности, дана отрицательная. Также в этой работе не содержится никаких упоминаний о Христе. Сочинения Юста в целом не дошли до нашего времени [Габелко, 2013, с. 200-205]. 
В кодексе 34 Фотий пишет о прочтении истории Юлия Африкана, бывшего также автором сочинения «Cesti» в 14 книгах: «Стиль его хотя и краток, но он ничего не пропускает, что достойно записи. Начинает он с космогонии Моисея и доходит до пришествия Христа. Также у него дается беглое описание событий, произошедших с того времени до правления Макрина. На этой дате хроника была закончена. Состоит работа из пяти книг. Также Африканом было написано письмо Оригену, где он опровергал подлинность истории Сусанны, приводя среди прочих то основание, что эта история не включена в еврейские книги. Оригеном был дан ответ, где он эти возражения опроверг. Также Африкан написал письмо к Аристиду, где показал, что между генеалогиями Спасителя у Луки и Матфея на самом деле нет никакой разницы».

Юлий Африкан является одним из первых христианских историков. Его «История» сохранилась во фрагментах у Иеронима и Евсевия. Письмо Оригену сохранилось в полном объеме, остальные работы - лишь частично. Можно сделать вывод, что Фотием оценка его работе дана в целом положительная.

В кодексе 116 речь идёт об анонимном сочинении «Третий том на праздник Святой Пасхи, в восьми книгах». Фотий, как обычно, оценивает «простой и очень ясный стиль» автора и отмечает, что в труде содержится множество здравых идей: «Автор в 4-й книге опровергает Метродора, помогая себе доказательствами из Писания. В его обсуждении Пасхи содержится много полезных замечаний в виде толкований о Создании. В этой работе автор подробным образом обсуждает все, что имеет отношение к теме. Он дает подробный и четкий отчет про високосный год и вставной месяц, эпакты луны и солнца, девятнадцать дней и способы их нахождения, о новолунии, о месяцах, какие годы называются интеркалярными и какие циклическими, о неделе и днях недели. Также он обсуждает 28 летний солнечный цикл, 19-летний лунный цикл и его 14-й день, солнечный и лунный месяцы, новолуние по солнечному и лунному месяцу, точный месяц и лунный месяц и расчет лет от сотворения мира. Он пишет, что наш Бог и Господь Христос, в соответствии с другими годами Его пришествия, участвовал в установлении праздника Пасхи, но в другой день, а не в тот, о котором сообщалось. Фотий считает, что это заслуживает внимания, так как Церковь и Златоуст учат, что перед тайной вечерей Он принял участие в регулярном празднике» [Henry, 1960, t. II, p. 210].

Так как труд анонимный, найти информацию о его авторе, его отношению к язычникам и об остальных трудах не представляется возможным. Можно только отметить, что труд оценен Фотием положительно, и кое-какие положения из этого сочинения были приняты им во внимание.

Эпоха раннего христианства не могла дать в настоящем смысле слова художественную литературу. Равновесие между содержанием и формой в его литературной продукции было еще резко нарушено в пользу содержания; декоративные элементы стилистики отвергались за ненужностью; жесткие установки на дидактическую «учительность» исключали внимание к внешнему оформлению [Kaldellis, 2008, p. 276]. Больше свободы себе позволяла повествовательная апокрифическая литература, которая иногда использовала приемы античного романа. Освоение христианством арсенала языческой культуры начиналось с философии; уже к началу III в. им выдвигается такой мыслитель, как Ориген, но не дается еще ни одного автора, который в формальном владении словом смог бы создать конкуренцию столпам «второй софистики» [Тревер, 1940, с. 59].

Лишь накануне эпохи Константина сближение с языческим обществом церкви и рост христианской культуры зашли так далеко, что создались объективные условия для соединения самых утонченных и разработанных форм риторики и христианской проповеди. Так закладывались основы византийской литературы [Kazhdan, 1991, с. 55].

Проанализируем протохристианские сочинения на соответствие догматам и с позиции отношения к ним патриарха Фотия. 
Анализ протохристианских сочинений с позиции отношения к ним Фотия

Analysis of proto-Christian writings from the position of Photius' attitude to them

\begin{tabular}{|c|c|c|c|c|}
\hline \begin{tabular}{c|c} 
№ \\
кодекса
\end{tabular} & Автор и название & $\begin{array}{l}\text { Общая оценка } \\
\text { работы Фотием }\end{array}$ & $\begin{array}{l}\text { Отношение к } \\
\text { язычникам }\end{array}$ & $\begin{array}{c}\text { Соответствие } \\
\text { работы } \\
\text { христианским } \\
\text { догматам }\end{array}$ \\
\hline 33 & $\begin{array}{l}\text { Юст из Тивериады. Хроника царей } \\
\text { иудейских }\end{array}$ & Отрицательная & $\begin{array}{c}\text { Ругает автора и его } \\
\text { работу }\end{array}$ & $\begin{array}{c}\mathrm{He} \\
\text { соответствует }\end{array}$ \\
\hline 34 & Юлий Африкан. История & Положительная & Автор не язычник & Соответствует \\
\hline 47 & Иосиф Флавий. Иудейская война & \multirow[t]{4}{*}{ Положительная } & \multirow{4}{*}{$\begin{array}{c}\text { Автор не язычник, } \\
\text { Фотий автора } \\
\text { одобряет }\end{array}$} & \multirow[t]{4}{*}{ Соответствует } \\
\hline 48 & Иосиф Флавий. О Вселенной & & & \\
\hline 76 & Иосиф Флавий. Иудейские древности & & & \\
\hline 238 & Иосиф Флавий. Иудейские древности & & & \\
\hline 116 & $\begin{array}{l}\text { Аноним. Третий том на праздник } \\
\text { Святой Пасхи, в восьми книгах }\end{array}$ & Положительная & $\begin{array}{c}\text { Автор не язычник, } \\
\text { Фотий автора } \\
\text { одобряет }\end{array}$ & Соответствует \\
\hline
\end{tabular}

Таким образом, можно сделать вывод, что среди сохранившихся кодексов «Мириобиблиона» протохристианских авторов немного. Среди исследованных нами язычников всего один отзыв Фотия крайне отрицательный. Остальные авторы и их работы оцениваются Фотием положительно и соответствуют христианским догматам. В целом данные работы принимаются и интегрируются в христианскую литературную традицию. Особое внимание Фотий в своих аннотациях сосредотачивает на характеристике жизни и учения Христа, причем интерес вызывает то, что это получается как бы «изнутри», а также на соотнесении взглядов писателей с христианским вероучением.

\section{Список литературы}

1. Блаватская Т.В. 1983. Из истории греческой интеллигенции эллинистического времени. М., Наука, 328.

2. Васильев А.А. 2012. Византийская империя. До крестовых походов. М., Алгоритм, 432.

3. Габелко О.Л. 2013. Эллинистический мир: Государства и правители. М., Российский гуманитарный научный фонд, 376.

4. Греческая философия. 2008. Под. ред. М. Канто-Спербер. М., Греко-латинский кабинет Ю.А. Шичалина, 978.

5. Зелинский Ф.Ф. 1996. Религия эллинизма. Томск, 88.

6. Иосиф Флавий. 1990. О древности иудейского народа: Против Апиона. Пер. Я.И. Израэльсона и Г.Г. Генкеля. М., XXXVI, 134 (in Russian).

7. Иосиф Флавий. 1961. Отрывки из «Иудейской войны» и «Иудейских древностей». Пер. А. Сыркина. Поздняя греческая проза. Сост. С. Поляковой. М., ГИХЛ, 29-62.

8. Иосиф (Петровых И.С.). 1903. История иудейского народа по археологии Иосифа Флавия: опыт критического разбора и обработки. Сергиев Посад, 484.

9. Кащеев В.И. 1993. Эллинистический мир и Рим: Война, мир и дипломатия в 220-146 гг. до н. э. М., ГЛК, 384.

10. Лемерль П. 2012. Первый византийский гуманизм. Замечания и заметки об образовании и культуре в Византии от начала до X века. Вступ. ст. и пер. с франц.: Т.А. Сенина (монахиня Кассия). СПб., Свое издательство, 490.

11. Мириобиблион. Библиотека Фотия - [Электронный ресурс] - http://simposium.ru/node/10517 (дата обращения: 10.05.2020).

12. Пети П. 2004. Эллинистические цивилизации. М., Астрель, 160. 
13. Плотников В.В. 2011. История христианского просвещения в его отношениях к древней греко-римской образованности: от торжества христианства при Константине Великом до окончательного падения греко-римского язычества при Юстиниане (313-529 гг.). М., ЛИБРОКОМ, 536.

14. Семеновкер Б. А. 1995. Библиографические памятники Византии. М., Археографический центр, 232.

15. Тревер К.В. 1940. Памятники греко-бактрийского искусства. М.; Л., Искусство, 240.

16. Шаму Ф. 2008. Эллинистическая цивилизация. Екатеринбург; М., АСТ, 480.

$\begin{array}{llll}17 . \text { Юлий Африкан. Пер. } & \text { В. Заславского. - [Электронный ресурс] }\end{array}$ http://myriobiblion.byzantion.ru/africanus/africanus2.html (дата обращения: 11.05.2020).

18. Kaldellis A. 2008. Hellenism in Byzantium. The Transformations of Greek Identity and the Reception of the Classical Tradition. Cambridge, University Press, 482.

19. Kazhdan A. 1991. Bibliotheca. The Oxford Dictionary of Byzantium. Oxford, University Press, 2232.

20. Photius. 1959. Bibliotheque, ed. R. Henry. Vol. I. Paris, Edition, 524.

21. Photius. 1960. Bibliotheque, ed. R. Henry, vol. II. Paris, Edition, 760.

\section{References}

1. Blavatskaya T.V. 1983. Iz istorii grecheskoj intelligentsii ehllinisticheskogo vremeni [From the history of the Greek intelligentsia of Hellenistic times]. Moscow, Nauka, 328 (in Russian).

2. Vasil'ev A.A. 2012. Vizantijskaya imperiya. Do krestovykh pokhodov [Byzantine empire. Before the Crusades]. M., Algorithm, 432 (in Russian).

3. Gabelko O.L. 2013. Ellinisticheskij mir: Gosudarstva i praviteli [Hellenistic world: States and rulers]. Moscow: Russian humanitarian scientific Foundation, 376 (in Russian).

4. Grecheskaya filosofiya [Greek Philosophy]. 2008. Pod. red. M. Kanto-Sperber [Edited by M. Kanto-Sperber]. M., Greek-Latin Cabinet of Yu. A. Shichalin, 978 (in Russian).

5. Zelinskij F.F. 1996. Religiya ehllinizma [The religion of Hellenism]. Tomsk, 88.

6. Iosif Flavij. 1990. O drevnosti iudejskogo naroda: Protiv Apiona. Per. Ya.I. Izraehl'sona i G.G. Genkelya [On the antiquity of the Jewish people: Against Apion. Per. Ya.I. Izraelson and G.G. Genkel]. M., XXXVI, 134 (in Russian).

7. Iosif Flavij. 1961. Otryvki iz «Iudejskoj vojny» i «Iudejskikh drevnostej» [Excerpts from the «Jewish war» and «Jewish antiquities»]. Per. A. Syrkina. Pozdnyaya grecheskaya proza [Late Greek prose]. Sost. S. Polyakovoj. Per. A. Syrkin. Comp. S. Polyakova. M., GIHL, 29-62 (in Russian).

8. Iosif (Petrovykh I.S.). 1903. Istoriya iudejskogo naroda po arkheologii Iosifa Flaviya: opyt kriticheskogo razbora i obrabotki [The history of the Jewish people in the archaeology of Josephus: experience of critical analysis and processing]. Sergiev Posad, 484 (in Russian).

9. Kashheev V.I. 1993. Ellinisticheskij mir i Rim: Vojna, mir i diplomatiya v 220-146 gg. do n. e. [The Hellenistic world and Rome: War, peace, and diplomacy in 220-146 BC]. M., GLK, 384 (in Russian).

10. Lemerl' P. 2012. Pervyj vizantijskij gumanizm. Zamechaniya i zametki ob obrazovanii i kul'ture v Vizantii ot nachala do X veka. Vstup. st. i per. s frants.: T.A. Senina (monakhinya Kassiya) [The first Byzantine humanism. Remarks and notes on education and culture in Byzantium from the beginning to the Tenth century. Introductory article and translation from French: T.A. Senina (nun Cassia)]. $\mathrm{SPb}$., Svoje publishing house, 490 (in Russian).

11. Miriobiblion. Biblioteka Fotiya [Myriobiblon. The library of Photius] - [Electronic resource] -http://simposium.ru/node/10517 (date accessed: 10.05.2020).

12. Peti P. 2004. Ellinisticheskie tsivilizatsii [Hellenistic civilizations]. M., Astrel, 160 (in Russian).

13. Plotnikov V.V. 2011. Istoriya khristianskogo prosveshheniya $\mathrm{v}$ ego otnosheniyakh $\mathrm{k}$ drevnej greko-rimskoj obrazovannosti: ot torzhestva khristianstva pri Konstantine Velikom do okonchatel'nogo padeniya greko-rimskogo yazychestva pri Yustiniane (313-529 gg.) [The history of Christian enlightenment in its relations to the ancient Greek-Roman education: from the triumph of Christianity under Constantine the Great to the final fall of Greek-Roman paganism under Justinian (313-529)]. M., LIBROKOM, 536 (in Russian).

14. Semenovker B.A. 1995. Bibliograficheskie pamyatniki Vizantii [Bibliographic monuments of Byzantium]. M., Archeographic center, 232 (in Russian). 
15. Trever K.V. 1940. Pamyatniki greko-baktrijskogo iskusstva [Monuments of Greek-Bactrian art]. M.; L., Iskusstwo, 240 (in Russian).

16. Shamu F. 2008. Ellinisticheskaya tsivilizatsiya [The Hellenistic civilization]. Yekaterinburg; M., AST, 480 (in Russian).

17. Yulij Afrikan. Per. V. Zaslavskogo [Julius Afrikanus. Per. V. Zaslavsky]. - [Electronic resource] -http://myriobiblion.byzantion.ru/africanus/africanus2.html (date accessed: 11.05.2020).

18. Kaldellis A. 2008. Hellenism in Byzantium. The Transformations of Greek Identity and the Reception of the Classical Tradition. Cambridge, University Press, 482.

19. Kazhdan A. 1991. Bibliotheca. The Oxford Dictionary of Byzantium. Oxford, University Press, 2232.

20. Photius. 1959. Bibliotheque, ed. R. Henry. Vol. I. Paris, Edition, 524.

21. Photius. 1960. Bibliotheque, ed. R. Henry, vol. II. Paris, Edition, 760.

\section{ИНФОРМАЦИЯ ОБ АВТОРЕ}

\section{Логвинова}

аспирант

Александра

Александровна, Россия

\section{INFORMATION ABOUT THE AUTHOR}

Alexandra A. Logvinova, Postgraduate Student, Department of General History, Belgorod National Research University, Belgorod, Russia 